\title{
Ionization basis for activation of enzymes soluble in ionic liquids
}

\author{
Guangnan $\mathrm{Ou}^{\mathrm{a}, \mathrm{b}^{*}}$, Biyan $\mathrm{He}^{\mathrm{a}}$ \& Peter Halling ${ }^{\mathrm{b}^{*}}$ \\ a School of Bioengineering, Jimei University, Xiamen 361021, P.R. China \\ b WestCHEM, Department of Pure and Applied Chemistry, University of Strathclyde, \\ Glasgow G1 1XW, U.K
}

\section{Abstract}

BACKGROUND: The complex interactions between electrolytes and proteins have been studied for more than a century. However, understanding is not yet complete and does not provide a basis for predicting the activity of enzymes in ionic media. The use of ionic liquids (ILs) as reaction medium has opened up new opportunities for better understanding of the mechanism of enzymatic catalysis. Although a number of properties of ILs have been correlated with enzyme function, these relationships are not completely understood at a molecular level. METHODS: We propose that ILs must be able to promote ionization of protein ionizable groups in order to dissolve active enzymes. The biocompatible IL need to possess a functional group with large donor number and acceptor number in both cationic and anionic units, each of which is based on a high dielectric constant lead structure. We designed and synthesized two series of ILs and determined their ionizing-dissociating abilities and activities of lipases soluble in these new ILs. RESULTS: The results showed that the ionizing-dissociating abilities of ILs paralleled the catalytic activity trend of lipases dissolved in the ILs. The activities of lipases soluble in the newly designed ILs were comparable to those in water. CONCLUSIONS: We can conclude that ionizing-dissociating abilities of an IL can be used as a basis for predicting the activity of enzymes soluble in the IL. GENERAL SIGNIFICANCE: Ionization basis for activation of enzymes gives a deeper understanding of the behavior of enzymes in non-aqueous media at a molecular level.

Keywords: ionization; activation; enzyme; ionic liquid

1 


\section{Introduction}

The complex interactions between electrolytes and proteins have been studied for more than a century $[1,2]$. However, understanding is not yet complete and does not provide a basis for predicting the activity of enzymes in ionic media. The use of ionic liquids (ILs) as reaction medium has opened up new opportunities for better understanding of the mechanism of enzymatic catalysis. Up to now, a number of properties of ILs have been correlated with enzyme function, such as anion nucleophilicity[3, 4], hydrophobicity[3-6], and kosmotropicity[7, 8], but these relationships are not completely understood at a molecular level. Therefore, it is necessary to develop a theoretical basis for predicting activity of enzymes in ILs.

To understand the behavior of enzymes in ILs at a molecular level, it is first desirable to dissolve enzymes in the solvents. For soluble catalysts, there are many relatively simple spectroscopic and other techniques for obtaining accurate information at a molecular level. Parker et al.[9] reported that cation solvating power of solvents is well measured by solvent donor properties (donor number, DN), while anion solvating power of solvents is well measured by solvent acceptor properties (acceptor number, AN). Water is a strongly amphoteric solvent with large DN and AN values $(\mathrm{DN}=33.0, \mathrm{AN}=54.8)[10]$. Enzymes are polyelectrolytes and can hence readily dissolve in water. And we might expect that active enzymes will tend to dissolve in water-like solvents with a hydroxyl-functionality. Walker and Bruce[11, 12] were the first to describe the design of an IL in which the cation contained a hydroxyalkyl group to stabilize the dissolved enzyme. The incorporation of a hydroxyl-functionality in the solvents for dissolving enzymes with modest to good catalytic activity was also demonstrated by several groups[13-15] including our own[16-18]. ILs based on other functional groups such as $\mathrm{NO}_{3}^{-}$, lactate, $\mathrm{EtSO}_{4}{ }^{-}$, and $\mathrm{CH}_{3} \mathrm{COO}^{-}$may also dissolve enzymes, however, most of them cause severe enzyme deactivation[3, 19-21]. What causes activation or deactivation of enzyme dissolved in ILs?

Figure 1 Activation and deactivation of enzyme dissolved in IL 
The behavior of enzymes is strongly dependent on the protonation state of their ionizable groups [17, 22-27]. Enzymes catalyze reactions using a variety of ionizable groups functioning as electrophiles, nucleophiles, or general acid/base catalysts. For an ionizable group (like - $\mathrm{COOH}$ ), the ionization process can be broken conceptually into two steps (Figure 1). In the first step, solvent molecules act as a Lewis base (electron pair donor) to the $\mathrm{H}$ atom and as a Lewis acid (electron pair acceptor) to the $\mathrm{O}$ atom, and ionize the $\mathrm{H}$ and $\mathrm{O}$ atoms, resulting in the breaking of the $\mathrm{O}-\mathrm{H}$ covalent bond and the formation of an ion pair $\left(\mathrm{O}^{-}, \mathrm{H}^{+}\right)_{\text {solv }}$ in which both ions now interact with solvent. The ionization step is a function of the $\mathrm{DN}$ and $\mathrm{AN}$ of the solvent. Higher values mean that solvent has higher ability to ionize polar $\mathrm{O}-\mathrm{H}$ covalent bond and to stabilize the formed ions. In other words, strongly amphoteric solvents are good ionizing solvents. In the second step, the ion pair $\left(\mathrm{O}^{-}, \mathrm{H}^{+}\right)_{\text {solv }}$ dissociates into free ions. The dissociation process is easy if the solvent has a high relative permittivity (dielectric constant, $\varepsilon_{\mathrm{r}}$ ).

According to the above analysis, solvents need to have water-like ionizing-dissociating abilities in order to dissolve active enzymes (In this paper we will refer to such solvents as "biocompatible".). Recently, we have proposed basic principles for biocompatible organic solvent design[18], which involve the introduction of hydroxyl groups into high dielectric constant compounds. The main objective of the solvent design is to improve ionizing-dissociating abilities of the studied solvent. The great success in designing biocompatible organic solvents in our previous studies $[17,18]$ inspired us to design and synthesize biocompatible ILs. The basic principles for biocompatible IL design are:

1. The design process starts with a known high dielectric compound used as a lead, so that the new IL has strong dissociating ability. Among common organic compounds, we found three classes of compounds that meet the demand, which can be used as lead compounds for construction of ILs. They are represented by dimethyl sulfone $\left(\varepsilon_{\mathrm{r}}=47.4\right.$ at $\left.383 \mathrm{~K}\right)$, triethanolamine $\left(\varepsilon_{\mathrm{r}}=29.4\right)$, and imidazole $\left(\varepsilon_{\mathrm{r}}=23.0\right)$ [28].

2. Starting from the structure of the selected lead, the IL is designed to have strong ionizing ability. This is the functionalization stage, and a functional group with 
large values of both DN and AN is built into the molecular structure of the lead compound. Hydroxyl group possesses high DN and AN values, therefore, hydroxyl-functionalization of the lead with high dielectric constant value may be advantageous for ionizing and dissociating enzyme functional groups. The incorporation of a hydroxyl-functionality in the high dielectric organic solvents for ionizing and dissociating enzymes with high catalytic activity was demonstrated by our group $[17,18]$.

3. The acid-base properties of the IL are important issues to consider because protonation changes caused by Brønsted-acidic or basic ions may result in enzyme deactivation[29]. Thereby, the acid-base properties of the newly designed IL need proper control for enzymes by selection of appropriate cation and anion types.

Biocompatible ILs were reported by several groups[13, 30-38] including our own[16]. Cations of these ILs do have a functional group with high AN and DN values, but their anions do not. Generally, both the cation and anion of an IL function cooperatively to affect the enzyme activity. We speculate that incorporation of a hydroxyl-functionality in both cationic and anionic units with high dielectric constant values may be advantageous for dissolving and ionizing enzymes. In addition, the newly designed ILs need to provide suitable acid-base environment for the enzymes. Enzymes tested in this work are lipases from Candida antarctica (CAL) and Pseudomonas cepacia (PCL) functioning in neutral environment, therefore, the newly designed ILs should be neutral. Following this rationale, we designed and synthesized two series of ILs (Scheme 1), hydroxyalkyl imidazolium hydroxyalkyl sulphonate $\left(\left[\mathrm{C}_{\mathrm{m}} \mathrm{OHMIM}\right]\left[\mathrm{HOC}_{\mathrm{n}} \mathrm{SO}_{3}\right]\right)$ and hydroxyalkyl tri(hydroxyethyl) ammonium hydroxylalkyl sulphonate $\left(\left[\mathrm{C}_{\mathrm{m}} \mathrm{OHTEA}\right]\left[\mathrm{HOC}_{\mathrm{n}} \mathrm{SO}_{3}\right]\right)$. We then determined their ionizing-dissociating abilities and their compatibility with lipase activity, in order to test the above hypothesis. 


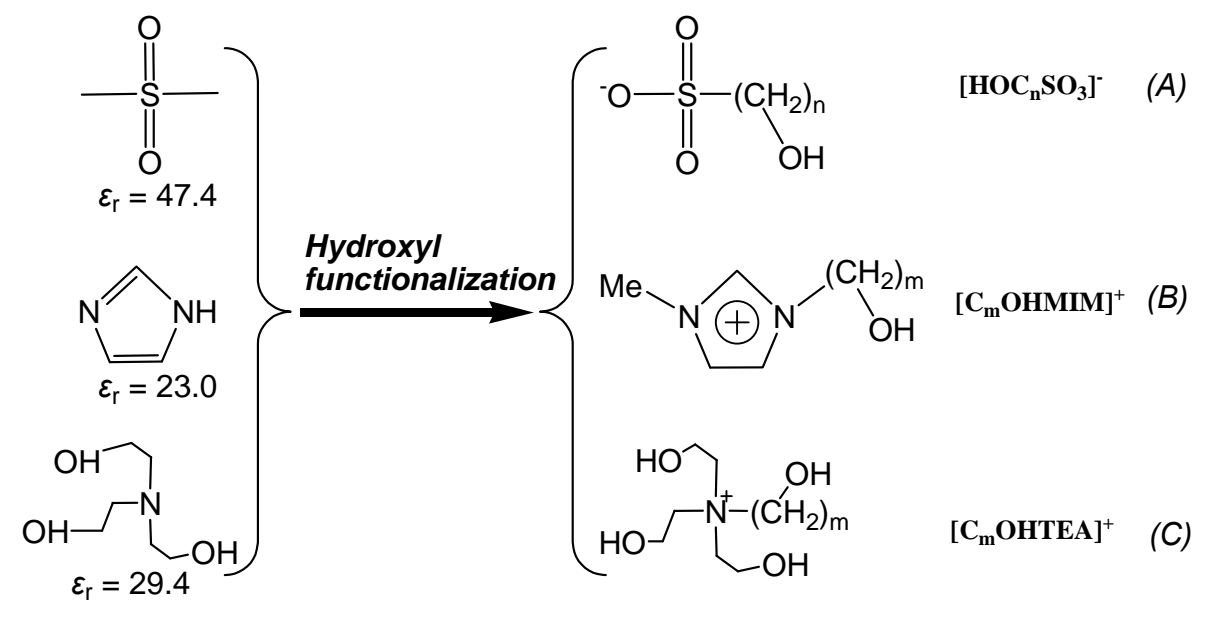

\section{Scheme 1 Design of biocompatible ILs}
(A) Anions based on sulfoxide
(B) Imidazolium-type Cations
(C) Ammonium-type Cations

\section{Materials and methods}

\subsection{General}

Candida antarctica lipase (CAL, $1.5 \mathrm{U} \mathrm{mg}^{-1}$ ) and Pseudomonas cepacia lipase (PCL, $30 \mathrm{U} \mathrm{mg}^{-1}$ ) were purchased from Sigma and used as supplied. All other chemicals and reagents were of analytical grade from Sigma. Ethyl butyrate, 1-butanol, 1-methylimidazole, triethanolamine, 2-chloroethanol, 3-chloro-1-propanol were dried by $3 \mathrm{~A}$ molecular sieves before use. $[\mathrm{BMIM}] \mathrm{NO}_{3}$ was synthesized according to published procedures and checked for the absence of chloride and acid[16].

The ${ }^{1} \mathrm{H}$ NMR and ${ }^{13} \mathrm{C}$ NMR spectra were obtained on a Brüker AV-400 or AV-600 Fourier transform NMR spectrometer. NMR spectra were referenced to tetramethylsilane. The mass spectra were analysed on the Agilent 6130 Dual Source ESI/APCI mass spectrometer or AB SCIEX Triple TOF 5600+.

\subsection{Synthesis of ILs}

\section{Synthesis of 1-(2-Hydroxyethyl)-3-methyl-imidazolium chloride $\left(\left[\mathrm{C}_{2} \mathrm{OHMIM}\right] \mathrm{Cl}\right)$ :} $\left[\mathrm{C}_{2} \mathrm{OHMIM}\right] \mathrm{Cl}$ was prepared by the method as described in the literature with minor modifications[39]. 2-Chloroethanol (64 mL, $0.95 \mathrm{~mol})$ and 1-methylimidazole (50 mL, $0.63 \mathrm{~mol}$ ) were added to a round-bottomed flask fitted with a reflux condenser for 24 $\mathrm{h}$ at $353 \mathrm{~K}$ with stirring. Ethyl acetate $(50 \mathrm{~mL})$ was added to extract the excess 
2-chloroethanol with thorough mixing and white crystals were obtained. The crystals were washed by ethyl acetate twice and then dried at $323 \mathrm{~K}$ under vacuum for $2 \mathrm{~d}$. (yield 92.5\%). ${ }^{1} \mathrm{H}$ NMR (400 MHz, $\mathrm{D}_{2} \mathrm{O}, 298 \mathrm{~K}$ ): 3.92-3.94 (overlapped, 5H), 4.34 (t, $\mathrm{J}=5.38 \mathrm{~Hz}, 2 \mathrm{H}), 7.50(\mathrm{~s}, 1 \mathrm{H}), 7.55(\mathrm{~s}, 1 \mathrm{H}), 8.80(\mathrm{~s}, 1 \mathrm{H}) ;{ }^{13} \mathrm{C} \mathrm{NMR}\left(400 \mathrm{MHz}, \mathrm{D}_{2} \mathrm{O}\right.$, $298 \mathrm{~K}): 36.01,51.71,59.95,122.59,123.71,136.47$.

\section{Synthesis of 3-hydroxypropyl-tri(2-hydroxyethyl) ammonium chloride}

([C C $_{3}$ OHTEA]CI): $\left.\left[\mathrm{C}_{3} \mathrm{OHTEA}\right)\right] \mathrm{Cl}$ was prepared by the method as described in the literature[13]. Triethanolamine $(0.5 \mathrm{~mol})$ and 3-chloro-1-propanol $(0.6 \mathrm{~mol})$ were added in a round bottom flask and refluxed at $363 \mathrm{~K}$ with stirring for $48 \mathrm{~h}$. The resulting mixture was washed three times with ethyl acetate to remove the starting materials. The IL was dried under vacuum for $24 \mathrm{~h}$ at $323 \mathrm{~K}$.

$\left.\left[\mathrm{C}_{3} \mathrm{OHTEA}\right)\right] \mathrm{Cl}$ (yield 87.1\%). ${ }^{1} \mathrm{H}$ NMR (400 MHz, $\left.\mathrm{D}_{2} \mathrm{O}, 298 \mathrm{~K}\right): 1.88-1.93$ (m, 2H), $2.65(\mathrm{t}, \mathrm{J}=6.12 \mathrm{~Hz}, 6 \mathrm{H}), 3.47-3.51(\mathrm{~m}, 2 \mathrm{H}), 3.55-3.59$ (overlapped, 8H); ${ }^{13} \mathrm{C} \mathrm{NMR}$ (400 MHz, D $2 \mathrm{O}, 298 \mathrm{~K}$ ): 23.97, 54.41, 55.10, 58.19, 60.57. ES-MS: ES ${ }^{+} m / z 208.3$ $\left[\mathrm{C}_{3}\right.$ OHTEA $\left.)\right]^{+}, 451.3\left[\mathrm{C}_{3}\right.$ OHTEA $\left.)\right]^{+} \cdots \mathrm{Cl}^{-} \cdots\left[\mathrm{C}_{3}\right.$ OHTEA $\left.)\right]^{+}$.

Synthesis of $\left.\left[\mathrm{C}_{\mathrm{m}} \mathrm{OHMIM}\right]\left[\mathrm{HOC}_{\mathrm{n}} \mathrm{SO}_{3}\right]\right)$ and $\left[\mathrm{C}_{\mathrm{m}} \mathrm{OHTEA}\right]\left[\mathrm{HOC}_{\mathrm{n}} \mathrm{SO}_{3}\right]$ : ILs were prepared by ion exchange method. The ion exchange of the anion chloride by the anion hydroxyalkanesulphonate was carried out using an exchange column packed with $100 \mathrm{~g}$ of Amberlite IR120 H-type strongly acidic cation exchange resin. The column was previously flushed thoroughly with a $1 \mathrm{~mol} \mathrm{~L}^{-1}\left[\mathrm{C}_{\mathrm{m}} \mathrm{OHMIM}\right] \mathrm{Cl}$ or $\left[\mathrm{C}_{\mathrm{m}} \mathrm{OHTEA}\right] \mathrm{Cl}$ solution until the elution was neutral, then with Milli-Q water until no chloride was detected by silver nitrate. A $100 \mathrm{~mL}$ of $1 \mathrm{~mol} \mathrm{~L}^{-1} \mathrm{Na}\left[\mathrm{HOC}_{\mathrm{n}} \mathrm{SO}_{3}\right]$ solution was slowly run over and eluted with Milli-Q water. The eluted liquid was collected and concentrated under reduced pressure in a rotary evaporator. The residue was then vacuum dried at $323 \mathrm{~K}$ for $18 \mathrm{~h}$ to afford the IL in near-quantitative yield as a colorless viscous liquid. ILs with ions containing hydroxyl groups are usually observed to be rather viscous.

\section{1-(2-Hydroxyethyl)-3-methyl-imidazolium hydroxymethane sulfonate}

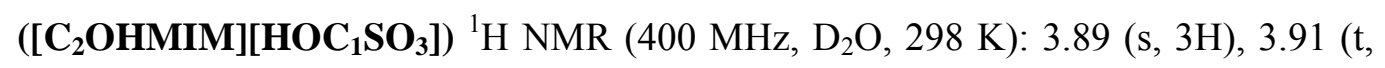
$\mathrm{J}=5.0 \mathrm{~Hz}, 2 \mathrm{H}), 4.30(\mathrm{t}, \mathrm{J}=4.83 \mathrm{~Hz}, 2 \mathrm{H}), 4.35(\mathrm{~s}, 2 \mathrm{H}), 7.44(\mathrm{~s}, 1 \mathrm{H}), 7.50(\mathrm{~s}, 1 \mathrm{H}), 8.72$ (s, 
$1 \mathrm{H}) ;{ }^{13} \mathrm{C}$ NMR (400 MHz, $\left.\mathrm{D}_{2} \mathrm{O}, 298 \mathrm{~K}\right): 35.29,51.08,59.35,73.71,122.01,123.18$, 135.92. ES-MS: $\mathrm{ES}^{+} m / z 127.00\left[\mathrm{C}_{2} \mathrm{OHMIM}\right]^{+}, 288.87\left[\mathrm{C}_{2} \mathrm{OHMIM}\right]^{+} \cdots \mathrm{H}_{3} \mathrm{O}_{2}{ }^{-} \cdots$ $\left[\mathrm{C}_{2} \mathrm{OHMIM}\right]^{+} ; \mathrm{ES}^{-} \mathrm{m} / z \quad 110.80 \quad\left[\begin{array}{llllll}\mathrm{HOC}_{1} \mathrm{SO}_{3} & ]^{-}, & 244.73 & {\left[\mathrm{HOC}_{1} \mathrm{SO}_{3}\right.}\end{array}\right]^{-} \cdots \mathrm{H}_{3} \mathrm{O}^{+} \cdots$ $\left[\mathrm{HOC}_{1} \mathrm{SO}_{3}\right]^{-}, 352.80\left[\mathrm{HOC}_{1} \mathrm{SO}_{3}\right]^{-\cdots}\left[\mathrm{C}_{2} \mathrm{OHMIM}\right]^{+} \cdots\left[\mathrm{HOC}_{1} \mathrm{SO}_{3}\right]^{-}$.

1-(2-Hydroxyethyl)-3-methyl-imidazolium 2-hydroxyethane sulfonate

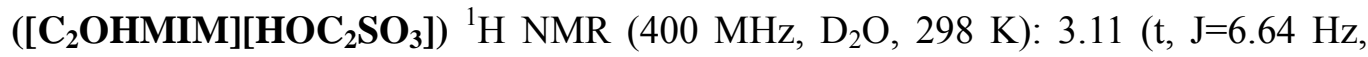
2H), 3.89 (s, 3H), 3.89-3.91 (overlapped, 4H), 4.30 (t, J=4.84 Hz, 2H), 7.44 (s, 1H), $7.50(\mathrm{~s}, 1 \mathrm{H}), 8.73(\mathrm{~s}, 1 \mathrm{H}) ;{ }^{13} \mathrm{C}$ NMR $\left(400 \mathrm{MHz}, \mathrm{D}_{2} \mathrm{O}, 298 \mathrm{~K}\right): 35.28,51.08,52.44$, 56.53, 59.34, 122.01, 123.18, 135.92. ES-MS: $\mathrm{ES}^{+} \mathrm{m} / z$ 127.00 $\left[\mathrm{C}_{2} \mathrm{OHMIM}\right]^{+}, 288.87$ $\left[\mathrm{C}_{2} \mathrm{OHMIM}\right]^{+} \cdots \mathrm{H}_{3} \mathrm{O}_{2}{ }^{-} \cdots\left[\mathrm{C}_{2} \mathrm{OHMIM}\right]^{+}, \quad 378.80 \quad\left[\mathrm{C}_{2} \mathrm{OHMIM}\right]^{+} \cdots\left[\mathrm{HOC}_{2} \mathrm{SO}_{3}\right]^{-} \cdots$ $\left[\mathrm{C}_{2} \mathrm{OHMIM}\right]^{+} ; \mathrm{ES}^{-} \mathrm{m} / z \quad 124.93 \quad\left[\mathrm{HOC}_{2} \mathrm{SO}_{3}\right]^{-}, \quad 272.87 \quad\left[\mathrm{HOC}_{2} \mathrm{SO}_{3}\right]^{-} \cdots \mathrm{H}_{3} \mathrm{O}^{+} \cdots$ $\left[\mathrm{HOC}_{2} \mathrm{SO}_{3}\right]^{-}, 376.67\left[\mathrm{HOC}_{2} \mathrm{SO}_{3}\right]^{-\cdots}\left[\mathrm{C}_{2} \mathrm{OHMIM}\right]^{+} \cdots\left[\mathrm{HOC}_{2} \mathrm{SO}_{3}\right]^{-}$.

3-hydroxypropyl-tri(2-hydroxyethyl) ammonium 2-hydroxyethane sulfonate ([C $\mathbf{C}_{3}$ OHTEA][HOC $\left.\mathbf{S O}_{3}\right]$ ) ${ }^{1} \mathrm{H}$ NMR (Brüker AV-600, $600 \mathrm{MHz}, \mathrm{D}_{2} \mathrm{O}, 298 \mathrm{~K}$ ): 1.92-1.93 (m, -OH), $3.06(\mathrm{t}, \mathrm{J}=6.55 \mathrm{~Hz}, 2 \mathrm{H}), 3.36$ (not resolved, 2H), 3.50-3.51 (m, 2H), 3.58 (not resolved, 6H), 3.86 (not resolved, 6H), 3.96 (not resolved, $4 \mathrm{H}$ ); ${ }^{13} \mathrm{C}$ NMR (Brüker AV-600, 600 MHz, D $2 \mathrm{O}, 298$ K): 24.61, 52.99, 55.06, 55.38, 55.47, 57.10, 58.36, 58.58, 61.25. ES-MS (AB SCIEX Triple TOF 5600+): $\mathrm{ES}^{+} \mathrm{m} / \mathrm{z}$ $208.1578\left[\mathrm{C}_{3} \mathrm{OHTEA}\right]^{+}, 266.2013 \mathrm{Na}^{+} \cdots \mathrm{H}_{3} \mathrm{O}_{2}{ }^{-} \cdots\left[\mathrm{C}_{3} \mathrm{OHTEA}^{+} ; \mathrm{ES}^{-} \mathrm{m} / z 124.9882\right.$ $\left[\mathrm{HOC}_{2} \mathrm{SO}_{3}\right]^{-}$

\subsection{Solubility of Protein in ILs}

Bovine serum albumin (BSA) is desirable because it is commercially available as a dried powder and readily dissolves in water. The solubility of powdered BSA in ILs were determined by absorbance assay. To a screw-top vial with a stir bar, IL (1000 $\mu \mathrm{L})$ and $10 \mathrm{mg}$ BSA were added. The mixture was stirred at $295 \mathrm{~K}$ at $300 \mathrm{rpm}$ over night. Samples were then centrifuged in an Eppendorf 5417R microcentrifuge at 16,000 g for 10 minutes, and the concentration of the saturated solution was determined from the absorbance at $280 \mathrm{~nm}$ using a Beckman Coulter DU 800 spectrophotometer. The solubility of powdered bovine serum albumin in $\left[\mathrm{C}_{2} \mathrm{OHMIM}\right]\left[\mathrm{HOC}_{1} \mathrm{SO}_{3}\right]$, 
$\left[\mathrm{C}_{2} \mathrm{OHMIM}\right]\left[\mathrm{HOC}_{2} \mathrm{SO}_{3}\right]$, and $\left[\mathrm{C}_{3} \mathrm{OHTEA}\right]\left[\mathrm{HOC}_{2} \mathrm{SO}_{3}\right]$ at $295 \mathrm{~K}$ were estimated from the absorbance at $280 \mathrm{~nm}$ as $0.9,2.5$, and $1.8 \mathrm{mg} \mathrm{mL}^{-1}$, respectively.

\subsection{Spectrophotometric Measurements of Ionizing Power of ILs}

In order to measure ionizing-dissociating abilities of ILs, the protonation equilibrium of 4-nitroaniline (PNA) in ILs was studied by means of spectrophotometric titration (eq. 1).

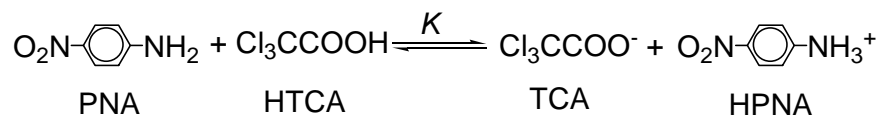

Because the new ILs are sticky liquids at room temperature, they were diluted with a little ethanol. Samples for a typical spectrophotometric measurement were prepared by mixing $1000 \mu \mathrm{L}$ of IL with $300 \mu \mathrm{L}$ ethanol, PNA solution $(50 \mu \mathrm{L})$, and trichloroacetic acid (HTCA) solution. PNA and HTCA were added as concentrated solution in ethanol. The PNA concentration was kept constant $\left(6.8 \times 10^{-5} \mathrm{~mol} \mathrm{~L}^{-1}\right)$. All spectrophotometric measurements were made at $370 \mathrm{~nm}$ with Beckman Coulter DU 800 spectrophotometer at $298 \pm 0.1 \mathrm{~K}$.

\subsection{UV/Visible measurement of myoglobin dissolved in buffered media}

BIS-Tris Propane (B) / $\mathrm{HCl}$ (A) buffer (molar ratio of [Base]/[Acid], $\mathrm{C}_{\mathrm{B}} / \mathrm{C}_{\mathrm{A}}$, ranged 0.7-13.3, $\mathrm{pH}$ in water 6.86-10.10) was used. The influence of $\mathrm{C}_{\mathrm{B}} / \mathrm{C}_{\mathrm{A}}$ on the protonation state of myoglobin were determined using Cary 50 spectrophotometer at $295 \pm 1$ K. Samples for a typical spectrophotometric measurement were prepared by adding $20 \mu \mathrm{L} 0.5 \mathrm{~mol} \mathrm{~L}^{-1}$ buffer aqueous solution of certain $\mathrm{C}_{\mathrm{B}} / \mathrm{C}_{\mathrm{A}}$ to $500 \mu \mathrm{L}$ solvent with stirring, followed by adding $10 \mu \mathrm{L}$ myoglobin solution $\left(10 \mathrm{mg} \mathrm{mL}^{-1}\right)$. Before samples were transferred into cuvettes, samples were centrifuged at $5000 \mathrm{rpm}$ for 2 min to remove air bubbles formed during vigorous stirring.

\subsection{General Procedures of Enzymatic Transesterification}

Lipase powder (1.0 mg for CAL, $2.0 \mathrm{mg}$ for PCL) was dissolved in $500 \mu \mathrm{L}$ of solvent in a $4 \mathrm{~mL}$ screw-top vial with a stir bar. Ethyl butyrate $(110 \mu \mathrm{L}, 0.83 \mathrm{mmol}), 1$-butanol (110 $\mu \mathrm{L}, 1.21 \mathrm{mmol}$ ), and $50 \mu \mathrm{L}$ cyclooctane (internal standard) were added. The reaction mixture was stirred at $323 \mathrm{~K}$ at $300 \mathrm{rpm}$ in an oil bath. For measurement of 
initial reaction rate, a $100-\mu \mathrm{L}$ aliquot of the reaction mixture was withdrawn at specified time intervals and extracted with four portions of heptane. The organic phase was analyzed using an Agilent 7890A gas chromatograph equipped with an FID and a capillary column $(\mathrm{HP}-5,30 \mathrm{~m} \times 0.32 \mathrm{~mm} \times 0.25 \mu \mathrm{m})$ and operated with a 1:4 split ratio using helium as the carrier gas. The analysis was performed under the following conditions: inlet port temperature $523 \mathrm{~K}$ and detector temperature $573 \mathrm{~K}$. The oven program consisted of an initial temperature of $313 \mathrm{~K}$ that was maintained for $1 \mathrm{~min}$ after which the temperature was increased at a rate of $30 \mathrm{~K} / \mathrm{min}$ to a final temperature of $523 \mathrm{~K}$.

\section{Results and discussion}

\subsection{Ionizing-dissociating abilities of ILs}

In order to measure ionizing-dissociating abilities of ILs, the protonation equilibrium of 4-nitroaniline (PNA) in ILs was studied by means of spectrophotometric titration. Because the new ILs are sticky liquids at room temperature, they were diluted with a little ethanol. This will affect the $\mathrm{K}$ values, but should not invalidate the order of magnitude differences we discuss below. Experimental data were subjected to fitting regression analysis according to eq 2 and 3.

$$
\begin{gathered}
K=\frac{[H P N A][T C A]}{[P N A][H T C A]} \\
K_{a}(H T C A)=\frac{[H]^{+}[T C A]}{[H T C A]}
\end{gathered}
$$

The $K$ value of the protonation equilibrium of PNA in $\left[\mathrm{C}_{2} \mathrm{OHMIM}\right]\left[\mathrm{HOC}_{1} \mathrm{SO}_{3}\right]$, $\left[\mathrm{C}_{2} \mathrm{OHMIM}\right]\left[\mathrm{HOC}_{2} \mathrm{SO}_{3}\right]$, and $\left[\mathrm{C}_{3} \mathrm{OHTEA}\right]\left[\mathrm{HOC}_{2} \mathrm{SO}_{3}\right]$ are close to that of water (Table 1), suggesting that the new ILs are the desirable solvents for enzymatic catalysis. The reason is that both the cation and anion of the ILs contain a hydroxyl group of high AN and DN values and have lead structures with high dielectric constant value (dimethyl sulfone $\left(\varepsilon_{\mathrm{r}}=47.4\right.$ at $\left.383 \mathrm{~K}\right)$, triethanolamine $\left(\varepsilon_{\mathrm{r}}=29.4\right)$, and imidazole $\left.\left(\varepsilon_{\mathrm{r}}=23.0\right) 27\right)$. By contrast, $K$ value in $[\mathrm{BMIM}] \mathrm{NO}_{3}$ is much less than that in water. This is because neither the cation nor anion of $[\mathrm{BMIM}] \mathrm{NO}_{3}$ contain any 
groups with high $\mathrm{AN}$ and $\mathrm{DN}$ values. The result indicated that $[\mathrm{BMIM}] \mathrm{NO}_{3}$ has poor ionizing-dissociating abilities and is hence not a suitable medium for dissolving active enzyme.

\subsection{Activities of lipases soluble in ILs}

To test the activities of CAL and PCL in dissolved form, we examined the lipase-catalyzed transesterification of ethyl butyrate with $n$-butanol. We compared enzymatic activity in ILs with that in water. All the reactions were performed under the same conditions, $323 \mathrm{~K}$ and $300 \mathrm{rpm}$, in this study to eliminate any temperature or mixing effects. The activities of lipases are shown in Table 1.

Table 1 Relationship between ionization behavior and activity of lipase in ILs

\begin{tabular}{llll}
\hline \multirow{2}{*}{ Solvent } & \multirow{2}{*}{$K^{a}$} & \multicolumn{2}{l}{ Initial rate $^{b} / \mu \mathrm{mol} \mathrm{h}^{-1} \mathrm{mg}^{-1}$} \\
\cline { 3 - 4 } & & $\mathrm{CAL}$ & $\mathrm{PCL}$ \\
\hline$\left[\mathrm{C}_{2} \mathrm{OHMIM}\right]\left[\mathrm{HOC}_{1} \mathrm{SO}_{3}\right]$ & $4-83$ & 6.1 & 1.4 \\
{$\left[\mathrm{C}_{2} \mathrm{OHMIM}\right]\left[\mathrm{HOC}_{2} \mathrm{SO}_{3}\right]$} & $0.9-2.0$ & 22.1 & 2.4 \\
{$\left[\mathrm{C}_{3} \mathrm{OHTEA}\right]\left[\mathrm{HOC}_{2} \mathrm{SO}_{3}\right]$} & $7-400$ & 19.3 & 3.7 \\
{$[\mathrm{BMIM}] \mathrm{NO}_{3}$} & $0.03-0.10^{c}$ & n.d. & n.d. \\
$\mathrm{H}_{2} \mathrm{O}$ & $0.8-5.3$ & 32.7 & 5.3 \\
\hline
\end{tabular}

a $K$ measurement conditions: $1000 \mu \mathrm{L}$ of solvent; $300 \mu \mathrm{L}$ of ethanol; PNA concentration $6.8 \times 10^{-5} \mathrm{~mol}$

$\mathrm{L}^{-1}$; temperature $298 \pm 0.1 \mathrm{~K}$; wavelength $370 \mathrm{~nm}$.

$b$ Reaction conditions: lipase powder (1.0 mg for CAL, $2.0 \mathrm{mg}$ for PCL); $500 \mu \mathrm{L}$ of solvent; $110 \mu \mathrm{L}$ of ethyl butyrate $(0.83 \mathrm{mmol}) ; 110 \mu \mathrm{L}$ of 1-butanol $(1.21 \mathrm{mmol})$; stirring speed $300 \mathrm{rpm}$; temperature $323 \mathrm{~K}$. The initial rate was expressed as micromoles of ethyl butyrate consumed per hour per milligram of lipase. The reaction products included butyric acid (in water) and possibly esters with the hydroxyl groups of the IL (which could not be detected by the GC method used). By measuring the rate of ethyl butyrate disappearance we include all enzymatic reactions.

$c$ Measurement conditions were the same as $a$ except that ethanol was replaced by water. n.d. means not detected (No activity was observed for lipases in the IL.).

The results showed that the ionizing-dissociating abilities of ILs ( $K$ value) paralleled the catalytic activity trend of lipases dissolved in the ILs. The activities of lipases in the newly designed ILs were comparable to those in water. The reason for the high initial reaction rate in the newly designed ILs is that the cation and anion of the IL possess a hydroxyl group with high DN and AN value and both cationic and anionic units have high dielectric constant lead structures. The incorporation of a 
hydroxyl-functionality in the high dielectric organic solvents for ionizing and dissociating enzymes with high catalytic activity was demonstrated by our group [17, 18]. In addition, the newly designed ILs are salts of a strong acid and a strong base, thereby they are neutral media. In other words, the newly designed ILs are water analogues with great ionizing-dissociating abilities, thereby the ILs can provide a suitable (i.e. non-denaturing, non-inhibitory) environment for non-aqueous biocatalysis, thus the activities of lipases in the ILs were comparable to those in water. The effect of a solvent on enzyme catalysis is, therefore, dependent on its donor-acceptor abilities and dielectric constant providing significant physicochemical driving forces for the ionization process of enzyme ionizable groups.

\subsection{Acid-alkaline transition of myoglobin soluble in ILs}

To gain insights into the effect of solvent on the protonation state of the protein, we chose myoglobin $(\mathrm{Mb})$ as model protein because $\mathrm{Mb}$ is a small (MW $17 \mathrm{kDa}$ ), stable heme protein and its conformation is sensitive to the acid-alkaline conditions. The spectroscopic properties of myoglobin $(\mathrm{Mb})$ in ILs and in water were examined at room temperature in a $19 \mathrm{mM}$ BIS-Tris Propane (B) / $\mathrm{HCl}(\mathrm{A})$ buffer over $\log \left(\mathrm{C}_{\mathrm{B}} / \mathrm{C}_{\mathrm{A}}\right)$ of -0.13 and 1.13 (Figure 2).

\section{Figure 2 The spectroscopic properties of Mb dissolved in buffered solvents.} BIS-Tris Propane (B) / $\mathrm{HCl}$ (A) buffer was used (molar ratio of [Base]/[Acid], $\mathrm{C}_{\mathrm{B}} / \mathrm{C}_{\mathrm{A}}$, ranged 0.7-13.3; $\mathrm{pH}$ in water ranged 6.86-10.10). Soret peak maximum for water is $408 \mathrm{~nm}\left(\mathrm{~A}_{\max }=\right.$ 1.478); for $\left[\mathrm{C}_{2} \mathrm{OHMIM}\right]\left[\mathrm{HOC}_{1} \mathrm{SO}_{3}\right] 412 \mathrm{~nm}\left(\mathrm{~A}_{\max }=0.749\right)$; for $\left[\mathrm{C}_{2} \mathrm{OHMIM}\right]\left[\mathrm{HOC}_{2} \mathrm{SO}_{3}\right] 403 \mathrm{~nm}$ $\left(\mathrm{A}_{\max }=0.754\right)$; for $\left[\mathrm{C}_{3} \mathrm{OHTEA}\right]\left[\mathrm{HOC}_{2} \mathrm{SO}_{3}\right] 404 \mathrm{~nm}\left(\mathrm{~A}_{\max }=0.864\right)$; for $[\mathrm{BMIM}] \mathrm{NO}_{3} 414 \mathrm{~nm}$ $\left(A_{\max }=1.059\right)$. All data were from Soret peak maxima.

For myoglobin dissolved in water, [C $\left.\mathrm{C}_{2} \mathrm{OHMIM}\right]\left[\mathrm{HOC}_{1} \mathrm{SO}_{3}\right]$, $\left[\mathrm{C}_{2} \mathrm{OHMIM}\right]\left[\mathrm{HOC}_{2} \mathrm{SO}_{3}\right]$, and $\left[\mathrm{C}_{3} \mathrm{OHTEA}\right]\left[\mathrm{HOC}_{2} \mathrm{SO}_{3}\right]$, the acid-alkaline transitions occurs over $\log \left(\mathrm{C}_{\mathrm{B}} / \mathrm{C}_{\mathrm{A}}\right)$ of -0.13 and 1.13. Acid-alkaline transitions observed in ferric hemeproteins are generally correlated to a change in the protonation status of an amino acid residue in the distal heme pocket $[40,41]$. The results suggested that 
solvent behaviors of $\left[\mathrm{C}_{2} \mathrm{OHMIM}\right]\left[\mathrm{HOC}_{1} \mathrm{SO}_{3}\right], \quad\left[\mathrm{C}_{2} \mathrm{OHMIM}\right]\left[\mathrm{HOC}_{2} \mathrm{SO}_{3}\right]$, and $\left[\mathrm{C}_{3} \mathrm{OHTEA}\right]\left[\mathrm{HOC}_{2} \mathrm{SO}_{3}\right]$ are similar to those of water. By contrast, no acid-alkaline transition was observed in $[\mathrm{BMIM}] \mathrm{NO}_{3}$. In neutral and alkaline environments, similar spectra without charge-transfer band at about $640 \mathrm{~nm}$ were observed in the optical spectrum of $\mathrm{Mb}$ in [BMIM] $\mathrm{NO}_{3}$ (Figure 3). According to study of Santucci et al.[42], $\mathrm{Mb}$ may undergo denaturation in $[\mathrm{BMIM}] \mathrm{NO}_{3}$ with splitting of the prosthetic group from the protein matrix.

\section{Figure 3 The spectroscopic properties of $\mathrm{Mb}$ dissolved in buffered solvents.}

BIS-Tris Propane (B) / $\mathrm{HCl}$ (A) buffer was used (molar ratio of [Base]/[Acid], $\mathrm{C}_{\mathrm{B}} / \mathrm{C}_{\mathrm{A}}$, is 0.7 ).

\section{Conclusions}

In conclusion, we developed a hypothesis that ionizing-dissociating abilities of an IL determine the activity of enzymes, and proposed basic principles for biocompatible IL design. The new biocompatible ILs need to possess a hydroxyl group with high DN and AN value in both cationic and anionic units, which units have high dielectric constant lead structure. In addition, the newly designed IL is a salt of a strong acid and a strong base, providing neutral environment for non-aqueous biocatalysis. The ionizing-dissociating abilities of ILs ( $K$ value) paralleled the catalytic activity trend of lipases dissolved in the ILs and the activities of lipases in the newly designed ILs were comparable to those in water. We can conclude that ionizing-dissociating abilities of an IL can be used as a basis for predicting the activity of enzymes dissolved in ILs.

\section{Acknowledgments}

We acknowledge the financial supports from the Education Department of Fujian Province, the Science Foundation of Jimei University, the NSF of Fujian Province (2015J01167), and the NSFC (41576085).

\section{References}

[1] F. Hofmeister, Zur Lehre von derWirkung der Salze, Arch. Exp. Pathol. Pharmakol. 24 (1888) 
247-260.

[2] R.A. Curtis, J. Ulrich, A. Montaser, J. Prausnitz, H. Blanch, Protein-protein interactions in concentrated electolyte solutions, Biotechnol. Bioeng. 79 (2002) 367-380.

[3] J.L. Kaar, A.M. Jesionowski, J.A. Berberich, R. Moulton, A.J. Russell, Impact of ionic liquid physical properties on lipase activity and stability, J. Am. Chem. Soc. 125 (2003) 4125-4131.

[4] H. Zhao, Protein stabilization and enzyme activation in ionic liquids: specific ion effects, J. Chem. Technol. Biotechnol. 91 (2015) 25-50.

[5] T. De Diego, A. Manjon, P. Lozano, M. Vaultier, J.L. Iborra, An efficient activity ionic liquid-enzyme system for biodiesel production, Green Chem. 13 (2011) 444-451.

[6] P. Vidya, A. Chadha, The role of different anions in ionic liquids on Pseudomonas cepacia lipase catalyzed transesterification and hydrolysis, J. Mol. Catal. B-Enzymatic 57 (2009) 145-148.

[7] H. Zhao, S.M. Campbell, L. Jackson, Z.Y. Song, O. Olubajo, Hofmeister series of ionic liquids: kosmotropic effect of ionic liquids on the enzymatic hydrolysis of enantiomeric phenylalanine methyl ester, Tetrahedron-Asymmetry 17 (2006) 377-383.

[8] Z. Yang, Hofmeister effects: an explanation for the impact of ionic liquids on biocatalysis, J. Biotechnol. 144 (2009) 12-22.

[9] A.J. Parker, U. Mayer, R. Schmid, V. Gutmann, Correlation of Solvent Effects on Rates of Solvolysis and Sn2 Reactions, J. Org. Chem. 43 (1978) 1843-1854.

[10] W.B. Jensen, The Lewis Acid-Base Definitions: A Status Report, Chem. Rev. 78 (1978) 1-22.

[11] A.J. Walker, N.C. Bruce, Combined biological and chemical catalysis in the preparation of oxycodone, Tetrahedron 60 (2004) 561-568.

[12] A.J. Walker, N.C. Bruce, Cofactor-dependent enzyme catalysis in functionalized ionic solvents, Chem. Comm. (2004) 2570-2571.

[13] D. Das, A. Dasgupta, P.K. Das, Improved activity of horseradish peroxidase (HRP) in 'specifically designed' ionic liquid, Tetrahedron Lett. 48 (2007) 5635-5639.

[14] M.D. Bermejo, M. Montero, E. Saez, L.J. Florusse, A.J. Kotlewska, M.J. Cocero, F. van Rantwijk, C.J. Peters, Liquid-Vapor Equilibrium of the Systems Butylmethylimidazolium Nitrate-CO2 and Hydroxypropylmethylimidazolium Nitrate-CO2 at High Pressure: Influence of Water on the Phase Behavior, J. Phy. Chem. B 112 (2008) 13532-13541.

[15] G. de Gonzalo, I. Lavandera, K. Durchschein, D. Wurm, K. Faber, W. Kroutil, Asymmetric biocatalytic reduction of ketones using hydroxy-functionalised water-miscible ionic liquids as solvents, Tetrahedron-Asymmetry 18 (2007) 2541-2546.

[16] G.N. Ou, J. Yang, B.Y. He, Y.Z. Yuan, Buffer-mediated activation of Candida antarctica lipase B dissolved in hydroxyl-functionalized ionic liquids, J. Mol. Catal. B-Enzymatic 68 (2011) 66-70.

[17] G.N. Ou, B.Y. He, Y.Z. Yuan, Lipases are soluble and active in glycerol carbonate as a novel biosolvent, Enzyme Microb. Technol. 49 (2011) 167-170.

[18] G.N. Ou, B.Y. He, Y.Z. Yuan, Design of Biosolvents Through Hydroxyl Functionalization of Compounds with High Dielectric Constant, Appl. Biochem. Biotechnol. 166 (2012) 1472-1479.

[19] R.M. Lau, M.J. Sorgedrager, G. Carrea, F. van Rantwijk, F. Secundo, R.A. Sheldon, Dissolution of Candida antarctica lipase B in ionic liquids: effects on structure and activity, Green Chem. 6 (2004) 483-487.

[20] H. Zhao, G.A. Baker, Z.Y. Song, O. Olubajo, L. Zanders, S.M. Campbell, Effect of ionic liquid properties on lipase stabilization under microwave irradiation, J. Mol. Catal. B-Enzymatic 57 (2009) 149-157. 
[21] M.B. Turner, S.K. Spear, J.G. Huddleston, J.D. Holbrey, R.D. Rogers, Ionic liquid salt-induced inactivation and unfolding of cellulase from Trichoderma reesei, Green Chem. 5 (2003) 443-447.

[22] A.M. Klibanov, Improving enzymes by using them in organic solvents, Nature 409 (2001) 241-246.

[23] G. Carrea, S. Riva, Properties and synthetic applications of enzymes in organic solvents, Angew. Chem. Int. Ed. 39 (2000) 2226-2254.

[24] E. Zacharis, B.D. Moore, P.J. Halling, Control of enzyme activity in organic media by solid-state acid-base buffers, J. Am. Chem. Soc. 119 (1997) 12396-12397.

[25] M.D. Joshi, G. Sidhu, I. Pot, G.D. Brayer, S.G. Withers, L.P. McIntosh, Hydrogen bonding and catalysis: A novel explanation for how a single amino acid substitution can change the $\mathrm{pH}$ optimum of a glycosidase, J. Mol. Biol. 299 (2000) 255-279.

[26] A.J. Russell, A.R. Fersht, Rational Modification of Enzyme Catalysis by Engineering Surface-Charge, Nature 328 (1987) 496-500.

[27] S. Brandsburg-Zabary, O. Fried, Y. Marantz, E. Nachliel, M. Gutman, Biophysical aspects of intra-protein proton transfer, Biochim. Biophys. Acta 1458 (2000) 120-134.

[28] J.G. Speight, Lange's handbook of chemistry, McGraw-Hill, New York, 2005.

[29] F. van Rantwijk, R.A. Sheldon, Biocatalysis in ionic liquids, Chem. Rev. 107 (2007) 2757-2785.

[30] X. Li, C. Zhang, S. Li, H. Huang, Y. Hu, Improving Catalytic Performance of Candida rugosa Lipase by Chemical Modification with Polyethylene Glycol Functional Ionic Liquids, Industrial \& Engineering Chemistry Research 54 (2015) 8072-8079.

[31] B.Q. Chen, Z. Guo, T.W. Tan, X.B. Xu, Structures of ionic liquids dictate the conversion and selectivity of enzymatic glycerolysis: Theoretical characterization by COSMO-RS, Biotechnol. Bioeng. 99 (2008) 18-29.

[32] Y. Abe, K. Kude, S. Hayase, M. Kawatsura, K. Tsunashima, T. Itoh, Design of phosphonium ionic liquids for lipase-catalyzed transesterification, J. Mol. Catal. B-Enzymatic 51 (2008) 81-85.

[33] H. Zhao, G.A. Baker, Z.Y. Song, O. Olubajo, T. Crittle, D. Peters, Designing enzyme-compatible ionic liquids that can dissolve carbohydrates, Green Chem. 10 (2008) 696-705.

[34] T. De Diego, P. Lozano, M.A. Abad, K. Steffensky, M. Vaultier, J.L. Iborra, On the nature of ionic liquids and their effects on lipases that catalyze ester synthesis, J. Biotechnol. 140 (2009) 234-241.

[35] Z. Guo, B. Chen, R.L. Murillo, T. Tan, X. Xu, Functional dependency of structures of ionic liquids: do substituents govern the selectivity of enzymatic glycerolysis?, Organic \& Biomolecular Chemistry 4 (2006) 2772-2776.

[36] Z. Guo, X.B. Xu, New opportunity for enzymatic modification of fats and oils with industrial potentials, Organic \& Biomolecular Chemistry 3 (2005) 2615-2619.

[37] H. Zhao, C.L. Jones, J.V. Cowins, Lipase dissolution and stabilization in ether-functionalized ionic liquids, Green Chem. 11 (2009) 1128-1138.

[38] D. Kahveci, Z. Guo, B. Ozcelik, X. Xu, Lipase-catalyzed glycerolysis in ionic liquids directed towards diglyceride synthesis, Process Biochem. 44 (2009) 1358-1365.

[39] L.C. Branco, J.N. Rosa, J.J.M. Ramos, C.A.M. Afonso, Preparation and characterization of new room temperature ionic liquids, Chemistry-a European Journal 8 (2002) 3671-3677.

[40] M.A. Marti, D.A. Estrin, A.E. Roitberg, Molecular Basis for the pH Dependent Structural Transition of Nitrophorin 4, Journal of Physical Chemistry B 113 (2009) 2135-2142.

[41] J.M. Swails, Y. Meng, F.A. Walker, M.A. Marti, D.A. Estrin, A.E. Roitberg, pH-Dependent Mechanism of Nitric Oxide Release in Nitrophorins 2 and 4, Journal of Physical Chemistry B 113 
(2009) 1192-1201.

[42] R. Santucci, E. Laurenti, F. Sinibaldi, R.P. Ferrari, Effect of dimethyl sulfoxide on the structure and the functional properties of horseradish peroxidase as observed by spectroscopy and cyclic voltammetry, Biochim. Biophys. Acta 1596 (2002) 225-233. 

Figure 2

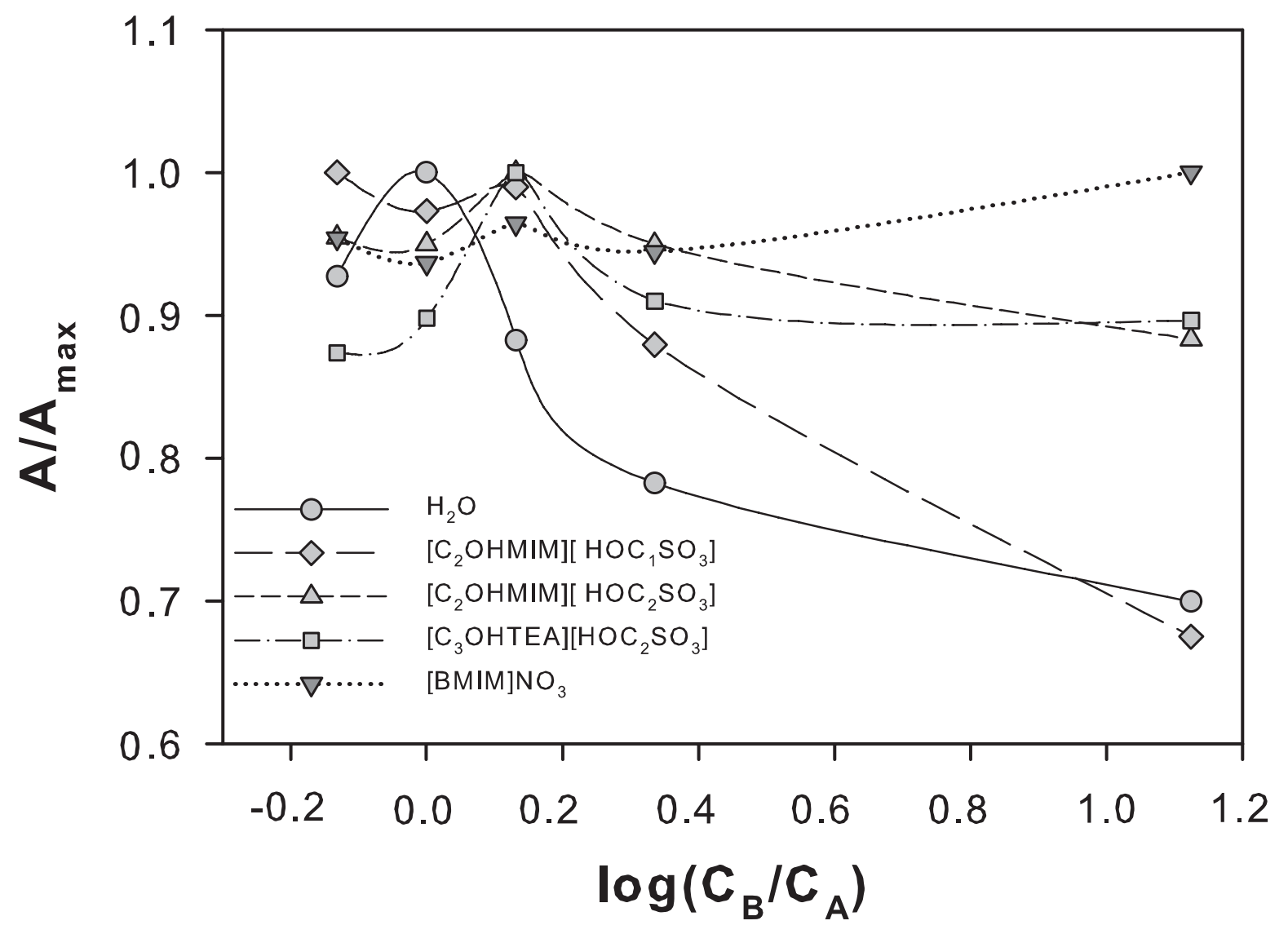


Figure 3

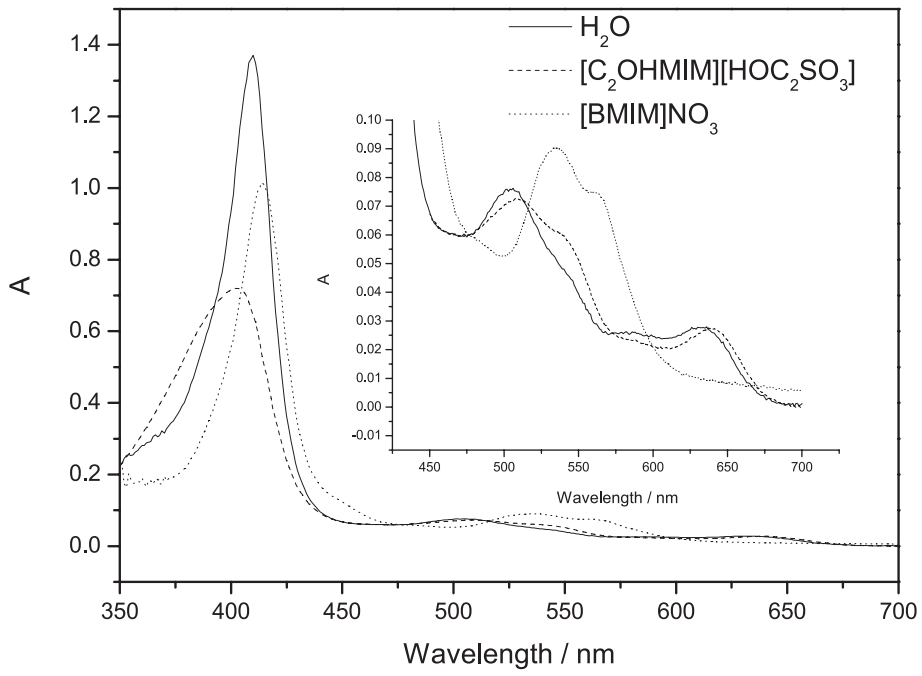

